\title{
DEVELOPMENT OF ECO-CULTURE TO IMPROVE ENVIROMENTAL LITERACY IN ELEMENTARY SCHOOL
}

\author{
Karenina Shashal Agsari, Mayang Kusumaning Rahady, Wahyudi \\ Universitas Sebelas Maret \\ shalshalkarenina@gmail.ac.id
}

Article History

accepted 30/09/2018

approved $12 / 10 / 2018$

published 30/10/2018

\section{Keywords}

echoculture, ecoliteracy

\begin{abstract}
The objectives of writing scientific papers are: (1) describing ecoculture, (2) describing ecoliteration of the environment, and (3)to describing ways to improve environmental ecoliteracy by means of eco-culture in elementary schools. The method used is literature study, which is data collection techniques by conducting study studies of books, literature, notes, and reports that are related to the problem being solved. Library sources in this study were obtained from: books, journals and research results (thesis, thesis, and dissertation). So that in this study include general processes such as: systematic theory identification, library discovery, and documentary analysis which contains information relating to the research topic. The results of this study are (1) eco-culture a process of increasing understanding, knowledge, attitudes and behavior based on ecology. (2) environmental echoliteration is to teach children to love the environment through greening. (3) improve environmental ecoliteracy in primary schools by take care and practicing directly maintaining and caring for the school environment.
\end{abstract}

Social, Humanities, and Education Studies (SHEs): Conference Series

p-ISSN 2620-9284 https://jurnal.uns.ac.id/shes e-ISSN 2620-9292 


\section{PENDAHULUAN}

Lingkungan merupakan tempat semua mahluk hidup berdampingan. Didalamnya terdapat komponen biotik dan abiotik yang saling mempengaruhi. Bila salah satu diantara komponen-komponen tersebut rusak, maka lingkungan mahluk hidup didalamnya akan terpengaruh atau bahkan musnah. Begitulah hukum alam terjadi. Jika lingkungan kita rusak maka banyak sekali dampak yang diberikan untuk lingkungan hidup kita contohnya bencana alam.

Bila kita cermati dengan baik beberapa kejadian akhir-akhir ini bencana alam yang semakin lama semakin sering terjadi, seperti yang dirilis media cetak Pikiran Rakyat, yaitu Banyaknya bencana longsor dan banjir menunjukkan Jawa Barat merupakan daerah dengan risiko bencana tinggi. Salah satu bencana yang banyak menelan korban jiwa diakibatkan oleh gerakan tanah. Dari sekitar 174 bencana gerakan tanah di Indonesia pada 2016, 87 kasus terjadi di Jawa Barat. Banyaknya bencana yang disebabkan lingkungan rusak ini mengakibatkan kerusakan alam. (Wibowo Rachma.dkk,2018)

Maka dari itu pendidikan lingkungan hidup sangat penting diajarkan sebagai usaha untuk melestarikan lingkungan yang dilakukakan dari generasi sekarang ke generasi yang akan datang. Secara eksplisit menunjukkan bahwa perjuangan manusia untuk melestarikan dan menyelamatkan lingkungan hidupnya, supaya tidak terjadi kepunahan dan tetap terjaga daya dukung lingkungan harus dilakukan secara berkesinambungan, dengan jaminan estafet antar generasi.

Oleh karena itu di era modern ini selain bencana alam yang dapat merusak ekosistem banyak juga masalah yang terjadi pada lingkungan. Hal tersebut tidak berasal dari alam saja yang dapat merusaknya melainkan manusia juga dapat merusak lingkungan seperti penebangan liar, pembuangan sampah di sungai, pembuangan limbah pabrik disungai dan membuang sampah sembarangan di area pantai.

Dilihat dari sekian banyaknya kerusakan alam yang disebabkan oleh manusia maka perlu diadakanya penanaman karakter sejak dini. Penanaman karakter sejak dini daiajarkan agar dapat menjadi dasar yang kuat bagi penanaman karakter peduli lingkungan. Karakter peduli lingkungan dapat ditanamkan berdasarkan kurikulum sekolah maupun program-program yang sudah direncanakan sekolah.

Kementrian Pendidikan Nasional (2010:15) mengemukakan upaya penanaman pendidikan karakter peduli lingkungan melalui kurikulum sekolah dan proses pembelajaran. Undang-Undang RI No.32 tahun 2009 tentang Perlindungan dan Pengelolaan Lingkungan Hidup menambahkan salah satu cara untuk menanamkan karakter peduli lingkungan melalui kesehatan lingkungan sekolah.

Pemerintah menggalakkan program ekoliterasi untuk menanamkan pendidikan karakter peduli lingkungan sejak dini. Penggalakan program ini diharapkan generasi penerus bangsa dapat menjaga dan melestarikan tumbuhan agar tetap terjaga dan dapat dirasan oleh generasi yang akan datang.

Pada era modern mulai banyak sekolah-sekolah khususnya sekolah dasar telah menerapkan program ekoliterasi ini. Program ekoliterasi ini tidak hanya mengembangkan kognitif peserta didik saja melainkan dapat mengembangkan sitem kerja motorik pada peserta didik.

Karena itu kurangnya perhatian dari masyarakat itu sendiri tentang lingkungan sehingga masyarakat kurang peduli akan kelestarian lingkungan. Hal tersebut dikarenakan kurang mengertinya masyarakat tentang eco-cultur dan ekoliterasi lingkungan. Sehingga masyarakat cenderung tidak peduli akan cara meningkatkan ekoliterasi dan ekokultur di lingkungan tersebut. Masyarakat belum mengerti apa manfaat yang didapatkan dari eco-cultur dan ekoliterasi.

Tujuan dari artikel itu sendiri bertujuan untuk lebih mengatahui dan mengerti tentang apa yang dimaksud ekokultur serta mengetahui apa yang dimaksud dengan 
ekoliterasi lingkungan. Serta untuk lebih mengetahui bagaimana cara meningkatkan ekoliterasi dengan cara ekokultur. Sehingga masyarakat dapat menerapkan program ekoliterasi dan eco-cultur agar lebih menjaga dan melestarikan lingkungan dan ekosistemnya.

\section{METODE}

Metode yang digunakan adalah studi kepustakaan Menurut Nazir (2003: 111) mengemukakan bahwa "studi kepustakaan adalah teknik pengumpulan data dengan mengadakan studi penelahan terhadap buku-buku, literatur, catatan-catatan, dan laporan-laporan yang ada hubungannya dengan masalah yang dipecahkan. Penelitian kepustakaan menurut Khatibah (2011:38) adalah Studi pustaka menempati posisi yang sangat penting dalam penelitian. Walaupun sebagian orang membedakan antara riset kepustakaan dan riset lapangan, akan tetapi keduaduanya memerlukan penelusuran pustaka.

Sumber-sumber kepustakaan dalam penelitian ini diperoleh dari : buku, jurnal dan hasil penelitian (skripsi, tesis, dan disertasi). Sehingga dalam penelitian ini meliputi proses umum seperti : megidentifikasikan teori secara sistematis, penemuan pustaka, dan analisis dokomen yang memuat informasi yang berkaitan dengan topik penelitian

A. Ekoliterasi

\section{HASIL DAN PEMBAHASAN}

Ekoliterasi adalah suatu proses peningkatan pemahaman, pengetahuan, sikap dan perilaku berlandaskan ekologi. Ekoliterasi berupaya memperkenalkan dan memperbaharui pemahaman seseorang akan pentingnya kesadaran ekologis global, guna menciptakan keseimbangan antara kebutuhan masyarakat dan kesanggupan bumi untuk menopangnya. (Sapanca putu lasmi yuliyanthi:04).

Ecoliteracy atau sering juga disebut dengan kecerdasan ekologi. Berasal dari kata Yunani yaitu oikos ("habitat") dan logos ("ilmu"). Kecerdasan ekologi adalah kemampuan kita untuk beradaptasi terhadap ekologis tempat kita berada. (Goleman 2010). Pemahaman mengenai ecoliteracy harus dimulai sejak dini. Penanaman sikap ramah lingkungan merupakan sikap yang harus dimiliki setiap individu. Individu yang memiliki kesadaran mengenai lingkungan akan dapat menselaraskan perkembangan pembangunan dengan lingkungan, sehingga tercipta lingkungan yang harmonis antara masyarakat dan lingkungan. Namun, sikap peduli terhadap lingkungan tidak akan hadir dengan sendirinya, perlu adanya pengenalan serta pembinaan agar sikap ini dapat mendarah daging pada diri siswa.

Goleman et al (Rusmana Neri Egi dan Aulia Akbar, 2017: 03) mengemukakan lima poin untuk mengembangkan sikap ecoliteracy yaitu sebagai berikut:

a) Develop Empathy For All Forms of Life

Pembelajaran harus memfokuskan kearah kesadaran, sikap merasakan (empati) akan lingkungan kepada siswa. Pada dasarnya setiap anak mempunyai kepakaan (empati) terhadap lingkungannya. Sikap ini dapat terlihat ketika siswa merasa kasihan terhadap mahluk hidup ketika disakiti. Sikap empati ini harus dikembangkan guru di kelas, sehingga rasa empati siswa semakin kuat. Melalui praktek yang berkelanjutan ini, anak-anak dapat menilai dan merenungkan apa yang dilakukannya baik atau buruk bagi lingkungan.

b) Embrace Sustainability as A Community Practice

Pembelajaran dalam kelompok perlu dilakukan siswa, agar siswa dapat bertanya jawab dengan teman kelompoknya. Selain itu, pembelajaran praktik secara berkelompok dapat menumbuhkan kesenangan tersendiri pada siswa serta dapat menumbuhkan rasa tanggung jawab terhadap tugas dan anggota 
kelompok yang lainnya. Siswa akan memahami bagaimana kelangsungan lingkungan adalah tanggung jawab setiap individu termasuk siswa.

c) Make the invisible visible

Pembelajaran nyata sangat diperlukan siswa. Siswa akan lebih dekat dan menjiwai setiap proses pembelajaran. Mereka dengan seksama mengikuti langkah langkah serta prosedur dalam kegiatan. Sehingga mereka akan merasakan apa yang menjadi tujuan pembelajaran. Hal ini akan menjadikan pembelajaran menjadi lebih bermakna. Siswa dapat merasakan secara langsung bagaimana pembelajaran merawat lingkungan.

d) Anticipate Unintended Consequences

Tahap ini akan maengajarkan siswa untuk bertanggung jawab penuh terhadap pekerjaannya. Akan ada akibat yang terjadi bila siswa menyepelekan tugasnya dalam proses pembelajaran. Kesalahan-kesalahan yang terjadi pada kegiatan atau proses belajar mengajar mengajarkan siswa akan perlunya kerjasama dan konsisiten terhadap tugasnya. Ketidaksesuaian harapan dengan kenyataan menjadi hal yang akan ditemukan siswa, sehingga siswa dapat mengevaluasi bagaimana seharusnya kegiatan yan

e) Understand How Nature Sustains Life

Kegiatan ini akan membawa siswa kedalam tahap evaluasi secara langsung. Siswa akan menyadari efek yang terjadi terjadi bila lingkungan tidak dipelihara dengan baik. Memahami bahwa kehidupan merupakan tanggung jawab manusia yang mengelolanya. Pengelolaan yang baik akan memberi efek baik bagi lingkungan dan begitu juga sebaliknya. Hal ini akan memberi pengalaman tersendiri untuk siswa.

B. Eco-Cultur

Eco-Cultur dalam Bahasa Inggris disebut Eco-Culture. Eco-Culture merupakan konsep pengembangan eco-green yang mengutamakan penghijauan sebagai bentuk penanggulangan global warming. Banyaknya bencana alam dan kerusakan tumbuhan di hutan ataupun di lingkungan sekitar menyebabkan kesadaran manusia untuk merawat lingkungan melalui penanaman ekoliterasi sejak dini. Hutan didefinisikan oleh Peraturan Menteri Kehutanan nomor P.03/MENHUT-V/2004 sebagai suatu hamparan lahan yang menjadi tempat tumbuhnya pohon-pohon yang kompak dan rapat di dalam wilayah perkotaan, baik pada tanah negara maupun tanah hak, yang ditetapkan sebagai hutan kota oleh pejabat yang berwenang.

Banyaknya tumbuhan yang mulai sedikit menyebabkan pemerintah tegas akan ikut ambil dalam melestarikan tumbuhan dan menggalakkan program ekoliterasi. Melalui pendidikan ekoliterasi sejak dini diharapkan masyarakat sadar akan pentingnya tumbuhan di dunia ini. Di era modern ini banyak mulai banyak rumah dan bangunan yang mengusung tema Eco-Cultur yang terlihat sangat asri. Sehingga banyak orang yang mulai minat akan budaya ekoliterasi ini.

Dengan program ekoliterasi ini dapat menciptakan Eco-Celture yang beragam yang dapat menambah sumber daya alam dan menambah daya tarik alam yang mempesona sehingga dapat menambah pesona alam. Banyaknya tempat wisata jaman sekarang mengusung tema alam yang dapat membuat mata para wisatawan ingin berkunjung.

Sedangkan maanfaat dari enerapan eco cultur ini jika diterapkan akan memiliki manfaat sebagai berikut:

1. Ecocultur suatu proses peningkatan pemahaman, pengetahuan, sikap dan perilaku berlandaskan ekologi.

2. Ekoliterasi lingkungan adalah mengajarkan anak untuk mencintai lingkungan melalui penghijauan. 
3. Meningkatkan ekoliterasi lingkungan di sekolah dasar dengan cara mengajarkan dan mempraktekan langsung menjaga dan merawat lingkungan sekolah.

\section{Literasi Sekolah}

Pada jaman milenial ini banyak teknologi berkembang. Perkembangan teknolgi ini berdampak pada proses globalisasi. Proses globalisasi sangat berkembang pesat pada abad ke-21 ini. Sehingga pada aman ini masyarakat lebih mengutamakan dan mengikuti perkembangan teknologi.

Perkembangan teknologi ini menyebabkan masyarakat lebih melek akan teknologi dan meninggalkan budaya literasi. Hal ini menyebabkan masyarakat kurang mengetahui akan informasi penting. Sehingga masyarakat kurang untuk berpikir kritis dalam menghadapi masalah pada masa yang akan datang.

Melihat dari peristiwa tersebut dapat kita lihat bahwa setiap lapisan masyarakat lebih membudayakan melek akan teknologi dibandingkan menambah ilmu dengan literasi. Karena banyaknya orang lebih memilih untuk menggunakan teknologi maka pemerintah menggalakkan program budaya literasi.

Program budaya literasi ini ditanamkan sejak dini oleh pemerintah. Agar masyarakat tidak hanya melek akan teknologi melainkan melek akan informasiinformasi yang penting. Sehingga masyarakat lebih berpikir kritis akan penyelesaian masalah yang akan datang.

Program ini dilaksanakan untuk anak usia dini. Agar anak bisa merawat dan menjaga lingkungan tempat tinggal. Dan diharapkan agar sumber daya tidak cepat habis sehingga anak dan cucu kita kelak dapat menikmati hasil alam pula.

Anak-anak diajarkan program ini agar anak-anak mengerti akan pentingnya menjaga alam. Karena alam adalah sumber daya penting untuk berkembangnya makhluk hidup dan ekosistem makhluk hidup.

\section{SIMPULAN}

Berdasarkan pembahasan diatas ekoliterasi adalah suatu proses peningkatan pemahaman, pengetahuan, sikap dan perilaku berlandaskan ekologi. Ekoliterasi berupaya memperkenalkan dan memperbaharui pemahaman seseorang akan pentingnya kesadaran ekologis global, guna menciptakan keseimbangan antara kebutuhan masyarakat dan kesanggupan bumi untuk menopangnya.

Banyaknya tumbuhan yang mulai sedikit menyebabkan pemerintah tegas akan ikut ambil dalam melestarikan tumbuhan dan menggalakkan program ekoliterasi. Melalui pendidikan ekoliterasi sejak dini diharapkan masyarakat sadar akan pentingnya tumbuhan di dunia ini.

Sedangkan maanfaat dari enerapan eco cultur ini jika diterapkan akan memiliki manfaat sebagai berikut:

1. Ecocultur suatu proses peningkatan pemahaman, pengetahuan, sikap dan perilaku berlandaskan ekologi.

2. Ekoliterasi lingkungan adalah mengajarkan anak untuk mencintai lingkungan melalui penghijauan.

3. Meningkatkan ekoliterasi lingkungan di sekolah dasar dengan cara mengajarkan dan mempraktekan langsung menjaga dan merawat lingkungan sekolah.

Perkembangan teknologi ini menyebabkan masyarakat lebih melek akan teknologi dan meninggalkan budaya literasi. Hal ini menyebabkan masyarakat kurang mengetahui akan informasi penting. Sehingga masyarakat kurang untuk berpikir kritis dalam menghadapi masalah pada masa yang akan datang.

Melihat dari peristiwa tersebut dapat kita lihat bahwa setiap lapisan masyarakat lebih membudayakan melek akan teknologi dibandingkan menambah ilmu dengan 
literasi. Karena banyaknya orang lebih memilih untuk menggunakan teknologi maka pemerintah menggalakkan program budaya literasi.

\section{DAFTAR PUSTAKA}

Goleman, Daniel. 2010. Eco Literate: How Educators are Cultivating Motional, Social, and Ecological Intelligence. US: Jossey Bass.

Khatibah. 2011. Penelitian Kepustakaan. Jurnal Iqra' Volume 05 No.01

Nazir, Mohammad. 2003. Metode Penelitian. Jakarta: Ghalia Indonesia.

Rusmana, Neri Egi. Aulia Akbar. 2017. Pembelajaran Ekoliterasi Berbasis Proyek Di Sekolah Dasar. Jurnal Edukasi Sebelas April Februari 2017 Vol. 1 No. 1.

Sapanca, Putu Lasmi Yuliyanthi. Etmagusti. Tanpa tahun. Efektivitas Ekoliterasi Dalam Meningkatkan Pengetahuan, Sikap Dan Perilaku Masyarakat Mengenai Education For Sustainable Development Berbasis Tanaman Pangan Lokal (Studi Kasus Di Kecamatan Bangli).

Wibowo,rachma.dkk. 2018. Ekokultur Arsitektur Pada Destinasi Wisata Pantai Nampu di Wonogiri. Jurnal 